\title{
Permian and Triassic ancestors of webspinners (Embiodea)
}

\section{Пермские и триасовые предки эмбий (Embiodea)}

\author{
Dmitry E. Shcherbakov \\ A.E. Щербаков
}

Borissiak Paleontological Institute, Russian Academy of Sciences, Moscow, Russia; dshh@narod.ru Палеонтологический институт им. А.А. Борисяка РАН, Москва, Россия.

KEY WORDS: Embiodea, Alexarasniidae, Protorthoptera, Atactophlebiidae, Sheimiidae, Miomoptera, wings, fossil, phylogeny.

КЛЮЧЕВЫЕ СЛОВА: Embiodea, Alexarasniidae, Protorthoptera, Atactophlebiidae, Sheimiidae, Miomoptera, крылья, ископаемые, филогения.

ABSTRACT. The extinct family Alexarasniidae known from isolated wings shows several characters considered unique of webspinners, including the radial blood sinus and hyaline intervenal lines, and therefore is assigned to Embiodea as Palembiodea subordo n. In this family, Nikolembia kusnezovi gen. et sp.n. from the terminal Permian (or basal Triassic) of Babiy Kamen', Kuznetsk Basin and Nestorembia novojilovi gen. et sp.n. from Middle or Late Triassic of Madygen, Kyrgyzstan are described. The latter genus is assigned to Nestorembiinae subfam.n. along with the monobasic Middle Triassic genus Palaeomesorthopteron Aristov, Grauvogel-Stamm et Marchal-Papier, 2011 originally described in the family Mesorthopteridae, order Grylloblattodea. Other pre-Cretaceous fossils related to webspinners are discussed. The webspinner lineage is traceable back via Jurassic Sinembiidae and Late PermianTriassic Alexarasniidae to the Early-Middle Permian Atactophlebiidae (Protorthoptera s.1.). Some embiid characters are found isolated in several protorthopteran families, including flexible wings with a radial blood sinus in Soyanopteridae and several blood sinuses in Soyaniidae fam.n. (created for Soyania Aristov et Rasnitsyn, 2009 described in Permembiidae Sheimiinae). Pseudosheimia alligans Aristov et Rasnitsyn, 2009 is singled out into Magniscapa gen.n. and its caudal appendages are reinterpreted as two-segmented cerci instead of male gonopods, discarding the argument in favor of assigning Sheimiidae, Letopalopteridae and Permembiidae to Oligoneoptera. The fossil evidence suggests that, contrary to common opinion, the slender body, short legs, enlarged hind femora, oligosegmented cerci, and flexible wings with sinus veins apparently evolved in webspinner ancestors living in confined spaces, long before the gallery-making habit.

РЕЗЮМЕ. Вымершее семейство Alexarasniidae, известное по изолированным крыльям, имеет несколько признаков, считающихся уникальными для эмбий, в том числе радиальный кровяной синус и прозрачные линии между жилками, и потому вклю- чено в Embiodea в качестве подотряда Palembiodea subordo n. В этом семействе описаны Nikolembia kusnezovi gen. et sp.n. из верхов перми или низов триаса Кузнецкого бассейна (Бабий Камень) и Nestorembia novojilovi gen. et sp.n. из среднего или позднего триаса Киргизии (Мадыген). Последний род отнесён к подсемейству Nestorembiinae subfam.n., как и монотипный среднетриасовый род Palaeomesorthopteron Aristov, Grauvogel-Stamm et MarchalPapier, 2011, который был описан в семействе Mesorthopteridae отряда Grylloblattodea. Обсуждаются другие домеловые ископаемые, сближавшиеся с эмбиями. Родословная эмбий прослеживается через юрских Sinembiidae и позднепермско-триасовых Alexarasniidae к ранне-среднепермским Atactophlebiidae (Protorthoptera s.1.). В нескольких семействах протортоптер возникали по отдельности некоторые признаки эмбий, в том числе гибкие крылья с радиальным синусом у Soyanopteridae и несколькими кровяными синусами у семейства Soyaniidae fam.n. (установлено для Soyania Aristov et Rasnitsyn, 2009, описанного в Permembiidae Sheimiinae). Pseudosheimia alligans Aristov et Rasnitsyn, 2009 выделен в род Magniscapa gen.n., и его хвостовые придатки реинтерпретированы как двучленистые церки, а не хватательные гоноподы самца, так что отпадает аргумент в пользу отнесения Sheimiidae, Letopalopteridae и Permembiidae к Oligoneoptera. Вопреки общему мнению, палеонтологические данные позволяют предположить, что тонкое тело, короткие ноги, увеличенные задние бедра, малочленистые церки и гибкие крылья с синусами по жилкам появились у скрытоживущих предков эмбий задолго до перехода к обитанию в паутинных галереях.

\section{Introduction}

Embiodea, or Embioptera is a minor order of Polyneoptera comprising some 400 described extant species found in warmer climates (up to $45^{\circ}$ latitude) 
worldwide. These small insects live subsocially in galleries made of silk produced by enlarged probasitarsi, hence the name "webspinners". The females are wingless and lack the ovipositor. The males are remarkable for a unique capability to temporary stiffen their otherwise totally flexible wings by increasing hemolymph pressure. This flexibility considered an adaptation to life in galleries is maintained by the main veins ( $\mathrm{R}-\mathrm{RA}$ and to a lesser degree $\mathrm{Sc}, \mathrm{CuA}-\mathrm{CuA} 2$ and A) transformed into inflatable blood sinuses and intercalary veins into hyaline folds; the RA is margined with border lines to accommodate turgescence and flattening of the radial sinus [Ross, 1940, 2000] (Fig. 1).

The oldest undeniable webspinners are known from mid-Cretaceous Burmese amber (Albian, 105 Ma) [Cockerell, 1919]. Engel and Grimaldi [2006] predicted that "the recovery of pre-Cretaceous webspinners... will be difficult since these typically small, soft-bodied insects are not well-preserved as compressions or replacements." The family Sinembiidae described as the earliest, Jurassic webspinners [Huang, Nel, 2009] was excluded from the order by Engel et al. [2011].

The Paleozoic fossils demonstrating some webspinner traits and formerly assigned to Embiodea were later transferred to Protorthoptera s.l. or Miomoptera. In the monobasic genus Soyania Aristov et Rasnitsyn, 2009 from the classic Middle Permian fossil site Soyana, Arkhangelsk Region, European Russia (Iva-Gora Beds, Lower Kazanian correlated to Lower Roadian, $\sim 271 \mathrm{Ma}$ ) described in the family Permembiidae [Aristov \& Rasnitsyn, 2009], several such traits are recognized here, and the genus is singled out into a new family (see Discussion).

Recently a monobasic family Alexarasniidae left unplaced within Polyneoptera was described [Gorochov, 2011] from the very rich Upper Permian fossil site Isady, Vologda Region, European Russia (Poldarsa Formation, Uppermost Severodvinian correlated to Lower Wuchiapingian, 258 Ma) [Golubev, 2013]. In

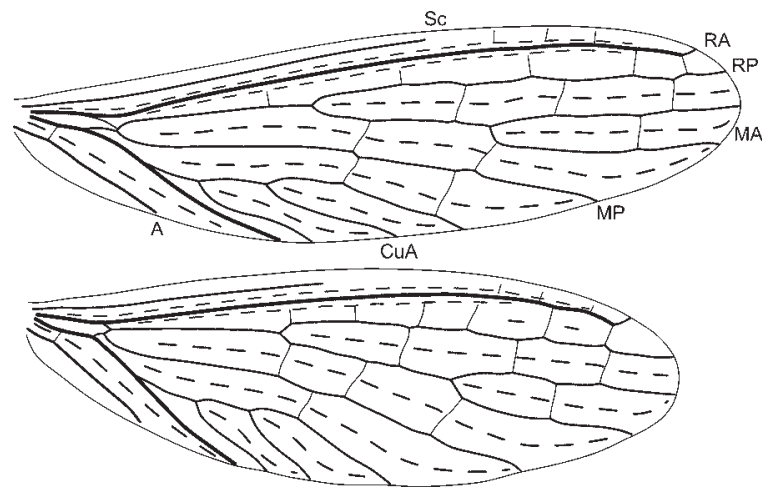

Fig. 1. Clothoda longicauda Ross, 1987, recent, venation of fore- and hind wing, based on Ross [1987, fig. 2]. Intervenal and radial border lines dashed.

Рис. 1. Clothoda longicauda Ross, 1987, современная, жилкование переднего и заднего крыла, по Ross [1987, fig. 2]. Междужилковые линии и краевые линии радиуса показаны пунктиром.
2013 the fossils described below as the second genus of Alexarasniidae were collected at Babiy Kamen', Kemerovo Region from the Mal'tsevo Formation, formerly considered Early Triassic, but now dated terminal Permian ( 253 Ma; see Discussion). In the Triassic Lagerstätte Madygen, Kyrgyzstan [Shcherbakov, 2008b] two isolated wings are found representing the third genus and the second subfamily of Alexarasniidae described below; the fourth genus is transferred from Grylloblattodea to this subfamily. Some embiid features in the wing structure of alexarasniids throw light on affinities of the family and the ancestry of webspinners.

The type material of the new taxa is deposited at the Borissiak Paleontological Institute, Russian Academy of Sciences (PIN). The specimens having both part and counterpart are indicated with " \pm ". Photographs were taken using a Leica M165C stereomicroscope with a Leica DFC425 digital camera and adjusted in Adobe Photoshop ${ }^{\circledR}$ CS3 10.0. Scanning electron micrographs of uncoated specimens were taken with a Tescan Vega microscope using backscattered electron detector.

\section{Taxonomy}

Order Embiodea Kusnezov, 1903, s.1.

REVISED DIAGNOSIS. Small to medium-sized. Wings homonomous, elongate, membranous, easily deformable. Veins not numerous (up to 13 branches on $\mathrm{R}, \mathrm{M}$ and $\mathrm{CuA}$ combined). Intercalary veins transformed into concave hyaline folds (intervenal lines, see Discussion) interrupting weak, irregular, usually not numerous crossveins; interradial line short or reduced. $\mathrm{R}$ and $\mathrm{M}$ forked close to wing base. R-RA stronger than other veins; RA (at least in middle part) margined with membranous, partly fleshy lines (radial border lines) indicating presence of radial blood sinus. Veins (often only intercalaries, i.e. intervenal lines) approaching posterior wing margin tend to form loops or deflect towards wing apex. Anal area short. Hind wing generally shorter and more oval than the forewing.

Suborder Euembiodea Shcherbakov, nom.n.

= Euembiaria Tillyard, $1937=$ Euembioptera Davis, $1940=$ Embiodea s. str.

DIAGNOSIS. RP and MA fused for considerable distance. MA forked (sometimes fork very long, up to almost $1 / 2$ wing length) or simple. CuA with 2-5(6) branches occupying minor part of wing surface; $\mathrm{CuA}-\mathrm{CuA} 2$ strong. $\mathrm{CuP}$ absent. One unbranched anal vein; anal area usually narrow. Radial border lines developed for most of wing length; interradial line weak or absent (see Discussion).

Suborder Palembiodea Shcherbakov, subordo n.

DIAGNOSIS. RP and MA free, not fused for a distance. MA simple, occasionally with short fork. CuA with 4-8 branches (all weak), sometimes occupying large part of wing surface. $\mathrm{CuP}$ developed as a vein. At least two anal veins with several branches; anal area relatively wide. Radial border lines developed along RA, interradial line only distally. 2011 
Family Alexarasniidae Gorochov, 2011

REVISED DIAGNOSIS. Small insects (body structure unknown) with elongate homonomous wings. $\mathrm{R}, \mathrm{M}$ and $\mathrm{CuA}$ forked near base; RA, RP, and MA simple or with short forks; MP simple or forked; $\mathrm{CuA}$ with up to 8 branches sometimes occupying large area; 2-3 anal veins. Radial border lines developed along RA. Longitudinal veins (including intercalaries) looped or deflected along posterior wing margin, sometimes forming ambient vein. Concave intercalary veins transformed into hyaline folds interrupting crossveins. Claval fold running anterior to $\mathrm{CuP}$. Crossveins sparse, irregular. Wing membrane wrinkled.

COMPOSITION. Two subfamilies.

SYSTEMATIC POSITION. Related to webspinners based on the presence of radial border lines, transformation of intercalaries into hyaline folds, vein looping/deflection along posterior margin, $\mathrm{R}, \mathrm{M}$ and $\mathrm{CuA}$ forked near wing base, similar number and distribution of the vein branches, crossvenation, wing shape, size and texture.

Key to THE GENERA AND SPECIES OF AlEXARASNIIDAe (WINGs)

1. $\mathrm{CuA}$ with 6-8 branches occupying large part of wing surface and almost reaching wing apex. MP simple or with short fork. Several posterior CuA branches looped, forming wavy ambient vein distant from wing margin and far not reaching wing apex ...... Alexarasniinae stat.n. ... 2

- $\mathrm{CuA}$ forked slightly proximal to $\mathrm{M}$, with 4 branches far not reaching wing apex; $\mathrm{CuA} 2$ simple. All $\mathrm{CuA}$ and $\mathrm{M}$ branches connected by smooth ambient vein running closely parallel to wing margin up to wing apex ...........

Nestorembiinae subfam.n. ... 3

2. $\mathrm{CuA}$ forked slightly distal to $\mathrm{M}$ or at same level; $\mathrm{CuA} 2$ forked. Wing membrane transversely wrinkled, suffused except for base of preradial area. Forewing nearly parallelsided, widest before midlength, with nearly parallel veins; preradial area slightly narrowed towards wing midlength; Sc proximally equidistant from $\mathrm{C}$ and $\mathrm{R}$, distally nearer to $\mathrm{C}$ than to RA; anal area almost $1 / 3$ wing length, relatively wide ................... Alexarasnia rossica Gorochov, 2011

- $\mathrm{CuA}$ forked slightly proximal to $\mathrm{M}$; $\mathrm{CuA} 2$ simple. Wing membrane irregularly wrinkled; apical wing quarter dark. Forewing widened distally, widest beyond midlength; veins diverging at level of Sc apex; preradial area much narrowed towards wing midlength; Sc proximally nearer to $\mathrm{C}$ than to $R$, distally nearer to $R A$ than to $C$; anal area about $1 / 4$ wing length, relatively narrow .

Nikolembia kusnezovi gen. et sp.n.

3. RP and MP simple. R forked distal to $\mathrm{CuA} 1$ bifurcation Palaeomesorthopteron pullus

Aristov, Grauvogel-Stamm et Marchal-Papier, 2011

- RP forked; MP forked before wing midlength. R forked proximal to $\mathrm{CuA} 1$ bifurcation

Nestorembia novojilovi gen. et sp.n.

Subfamily Alexarasniinae Gorochov, 2011, stat.n.

COMPOSITION. Type genus and Nikolembia gen.n.

REMARKS. Alexarasnia rossica was described from a single forewing represented by both part and counterpart (Figs 2-3). In the original drawing [Gorochov, 2011, fig. 1] based on the incomplete counterpart (negative impression), venation of the missing apex is shown in dashed line, with a fork on MP, but in fact the MP is simple as seen in the complete but less well preserved part (positive impression; Fig. 2). In the counterpart the radial border lines along the proximal RA and intervenal lines are very clearly seen (Fig.

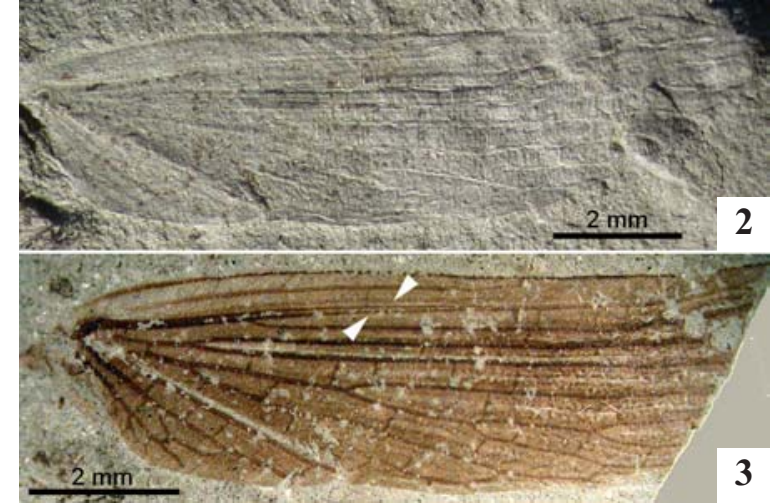

Figs 2-3. Alexarasnia rossica Gorochov, 2011, Isady, Upper Permian, holotype forewing: 2 - positive impression; 3 - negative impression (mirror image); arrows, radial border lines.

Рис. 2-3. Alexarasnia rossica Gorochov, 2011, Исады, верхняя пермь, голотип, переднее крыло: 2 - прямой отпечаток; 3 обратный отпечаток (повёрнут зеркально); стрелки - краевые линии радиуса.

$3)$. Another wing from the same site, assigned to Alexarasniidae gen. et sp. indet. by Gorochov [2011] and differing from the $A$. rossica holotype in the MP bearing a short fork, more branched $\mathrm{CuA}$, more divergent longitudinal veins, and shorter anal area, agrees with it in many other characters and is likely a hind wing of the same species.

Nikolembia Shcherbakov, gen.n.

TYPE SPECIES. Nikolembia kusnezovi sp.n.

DIAGNOSIS. Distinct from Alexarasnia in the $\mathrm{CuA}$ forked more proximal with $\mathrm{CuA} 2$ simple, and in the structure of preradial area, smaller anal area, and shape of the forewing (see the key).

COMPOSITION. Type species.

ETYMOLOGY. The genus and its type species are named after Nikolai Ya. Kuznetsov (N.J. Kusnezov), Russian entomologist and paleoentomologist, author of the name Embiodea. The generic name is feminine.

\section{Nikolembia kusnezovi Shcherbakov, sp.n.}

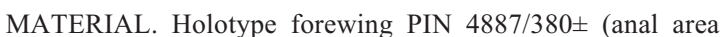
missing) and paratypes PIN 4887/381 (hind wing; very base missing, preradial area deformed proximally), $382 \pm$ (poorly preserved hind wing), 394 (basal part of forewing); Babiy Kamen', right bank of Tom' River, 10 km downstream from village of Ust'-Naryk, Kemerovo Region; Kedrovka beds, Mal'tsevo Formation, uppermost Permian (or lowermost Triassic).

DESCRIPTION (Figs 4-8). Forewing (9.7 mm long, holotype) 3.5 times as long as wide, much widened distally, widest beyond midlength, obliquely rounded apically; veins diverging at level of Sc apex; costal margin slightly concave before wing midlength, preradial area much narrowed there; Sc proximally nearer to $C$ than to $R$, distally nearer to RA than to C; MA with apical fork; MP simple; CuA with 8 branches, basally pectinate with three posterior branches, $\mathrm{CuA} 2$ simple; several posterior cubital branches looped forming wavy ambient vein distant from wing margin, anterior ones deflected towards apex; anal area rather narrow (judging by wing outline); radial border lines traceable along proximal RA; intervenal lines distinct, deep, interradial one developed only distally, intermedial one proximally stronger and bordering MP; interradial space slightly widened before apex. Hind wing ( $7.9 \mathrm{~mm}$ long as preserved, about $8.5 \mathrm{~mm}$ long; paratype 


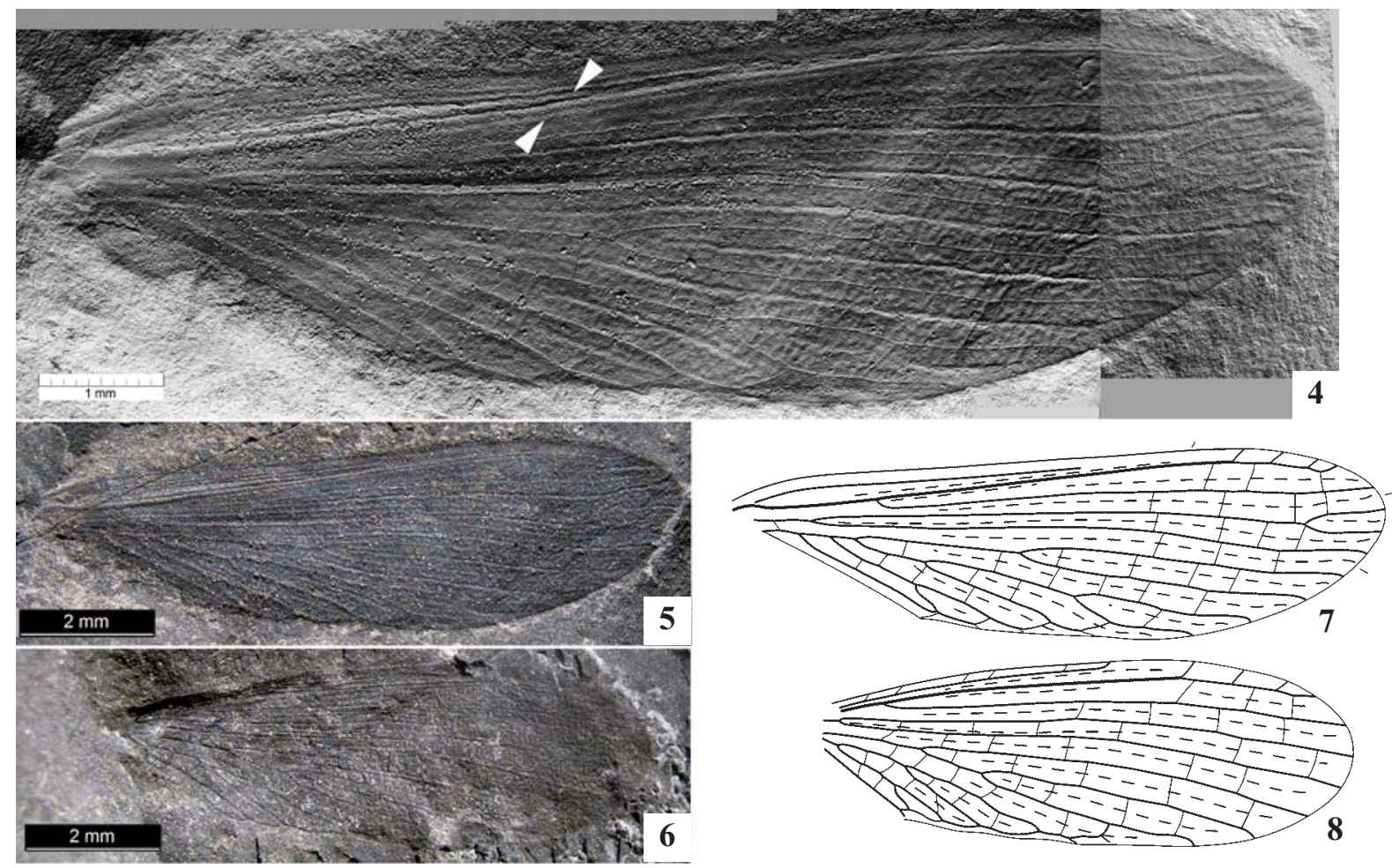

Figs 4-8. Nikolembia kusnezovi sp.n., Babiy Kamen', uppermost Permian (or lowermost Triassic): 4-5, 7 - holotype forewing PIN 4887/ 380: 4 - negative impression (mirror image, composed of four SEM micrographs, apex from positive impression); 5 - positive impression; 7 - venation; 6, 8 - paratype hind wing PIN 4887/381: 6 - positive impression (mirror image); 8 - venation; arrows, radial border lines.

Рис. 4-8. Nikolembia kusnezovi sp.n., Бабий Камень, верхи перми (или низы триаса): 4-5, 7 - голотип ПИН 4887/380, переднее крыло: 4 - обратный отпечаток (повернут зеркально, составлен из четырех СЭМ микрофотографий, вершина от прямого отпечатка); 5 - прямой отпечаток; 7 - жилкование; 6,8 - паратип ПИН 4887/381, заднее крыло: 6 - обратный отпечаток (повернут зеркально); 8 - жилкование; стрелки - краевые линии радиуса.

4887/381) about 3.1 times as long as wide, slightly widened distally, narrowly rounded apically; costal margin convex; Sc distally nearer to $\mathrm{C}$ than to RA; venation similar, except for MA simple. Wing membrane irregularly wrinkled. Veins and apical wing quarter dark (boundary of dark area oblique in forewing).

Subfamily Nestorembiinae Shcherbakov, subfam.n.

TYPE GENUS. Nestorembia gen.n.

DIAGNOSIS. Distinct from Alexarasniinae in the less branched $\mathrm{CuA}$ and well developed ambient vein (see the key).

COMPOSITION. Type genus and Palaeomesorthopteron Aristov, Grauvogel-Stamm et Marchal-Papier, 2011.

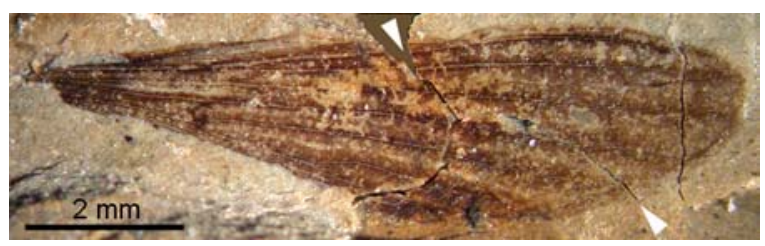

Fig. 9. Palaeomesorthopteron pullus Aristov, Grauvogel-Stamm et Marchal-Papier, 2011, Gottenhouse, Middle Triassic, holotype forewing (broken and glued), edited photograph (the fragment dista to arrows returned into natural position).

Рис. 9. Palaeomesorthopteron pullus Aristov, Grauvogel-Stamm et Marchal-Papier, 2011, Gottenhouse, средний триас, голотип, переднее крыло (разбит и склеен), отредактированная фотография (фрагмент дистальнее стрелок возвращен в исходное положение)
REMARKS. Palaeomesorthopteron pullus Aristov, Grauvogel-Stamm et Marchal-Papier, 2011 from the Middle Triassic (Anisian) of Vosges, France was originally placed in Mesorthopteridae (Grylloblattodea) [Aristov et al., 2011] despite salient differences from all known genera of this family (Fig. 9).

\section{Nestorembia Shcherbakov, gen.n.}

TYPE SPECIES. Nestorembia novojilovi sp.n.

DIAGNOSIS. Distinct from Palaeomesorthopteron in the deeply forked MP and forked RP (see the key).

COMPOSITION. Type species.

ETYMOLOGY. The genus and its type species are named after Nestor I. Novojilov, Russian paleontologist, an ardent explorer of the Madygen fossil beds. The generic name is feminine.

\section{Nestorembia novojilovi Shcherbakov, sp.n.}

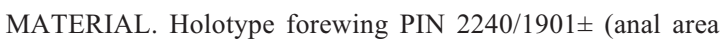
torn off, lying beside) and paratype hind wing PIN 2785/2252 (proximal part of preradial area tucked under); Dzhailoucho near village of Madygen, Batken Region, Kyrgyzstan; Madygen Formation, Ladinian-Carnian, Middle or Upper Triassic.

DESCRIPTION (Figs 10-14). Forewing $12.4 \mathrm{~mm}$ long, widened distally, widest beyond midlength; veins diverging at level of Sc apex; costal margin slightly concave before wing midlength; RP and MA with terminal forks; MP and $\mathrm{CuA} 1$ forked before wing midlength; $\mathrm{CuA} 1$ pectinate forwards, $\mathrm{CuA} 2$ simple; posteriormost branch of $\mathrm{CuA} 1$ deflected towards apex parallel to ambient vein; ambient vein run- 


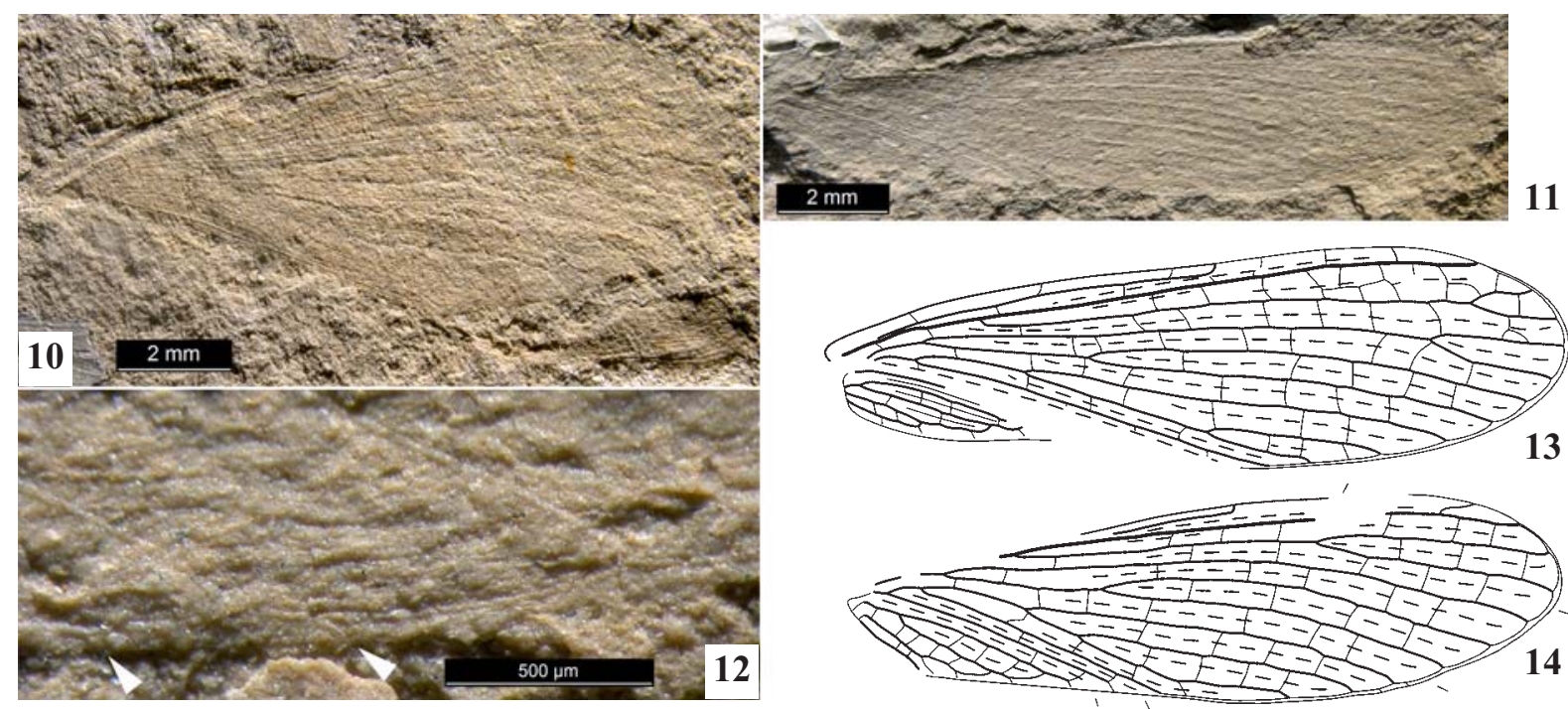

Figs 10-14. Nestorembia novojilovi sp.n., Madygen, Middle or Upper Triassic: 10, 13 — holotype forewing PIN 2785/2252: 10 positive impression (mirror image); 13 - venation; 11-12, 14 - paratype hind wing PIN 2240/1901: 11 - positive impression; 12 ambient vein (arrows, free apices of CuA1 branches between ambient vein and wing margin); 14 - venation (13-14 — reduced to same length/width ratio ca. 3.5:1).

Рис. 10-14. Nestorembia novojilovi sp.n., Мадыген, средний или верхний триас: 10, 13 - голотип ПИН 2785/2252, переднее крыло: 10 - прямой отпечаток (повернут зеркально); 13 - жилкование; 11-12, 14 - паратип ПИН 2240/1901, заднее крыло: 11 прямой отпечаток; 12 - обходящая жилка (стрелки, свободные вершины ветвей СuA1 между обходящей жилкой и краем крыла); 14 - жилкование (13-14 — приведены к одинаковому соотношению длины и ширины около $3.5: 1$ ).

ning very close to wing margin (free vein apices visible between them); $\mathrm{CuP}$ well developed; anal area longer than $1 / 2$ wing; $1 \mathrm{~A}$ forked near base, $2 \mathrm{~A}$ and $3 \mathrm{~A}$ simple, all anal veins looped near margin; intervenal lines distinct, deep, interradial one developed only distally, intermedial one weak proximally; interradial space distally widened, with rudimentary double row of cells. Hind wing $13.3 \mathrm{~mm}$ long, with similar venation, except for RP forked about $2 / 3$ wing length, MA simple, anal area shorter than $1 / 2$ wing, and interradial space not widened. Wings suffused, costal space pale.

REMARKS. Due to linear distortion of the rock matrix at Dzhailoucho the fossils are deformed, so that intraspecific variation in size and shape is exaggerated, and the wing length/width ratio can be misleading. For example, the $N$. novojilovi sp.n. forewing is 2.5 times as long as wide and a similar hind wing assigned to the same species is 4.5 times as long as wide, the former apparently distended crosswise and the latter lengthwise. Another difference between the foreand hind wing, in the degree of development of RP and MA forks, is not of much importance, so far as such differences occur as individual aberrations in webspinners (e.g. Calamoclostes albistriolatus Enderlein, 1909) [Ross, 1944].

Order Protorthoptera Handlirsch, 1906, s.1.

Family ?Sheimiidae Martynova, 1958

REMARKS. Aristov \& Rasnitsyn [2009] included the families Sheimiidae and Letopalopteridae Martynova, 1961 as subfamilies in Permembiidae Tillyard, 1937 and assigned the latter to Miomoptera in Oligoneoptera. The first action seems insufficiently substantiated because of great differences of the respective type genera, and the second is not accepted since the caudal appendages of Pseudosheimia alligans Aristov et Rasnitsyn, 2009 originally interpreted as forceps-like male gonopods are in fact cerci (see below). This species differing markedly from its congeners is separated into a new genus.

\section{Magniscapa Shcherbakov, gen.n.}

TYPE SPECIES. Pseudosheimia alligans Aristov et Rasnitsyn, 2009

DIAGNOSIS. Distinct from Pseudosheimia Aristov, 2004 in the greatly enlarged scape of antenna, subquadrate pronotum, curved distal RA, RP+MA anastomosis absent, numerous crossveins in the forewing, and massive two-segmented cerci.

COMPOSITION. Type species.

ETYMOLOGY. From Latin magnus (great) and scapus (shaft); gender feminine.

REMARKS. Many differences from Sheimia Martynova, 1958 indicate that the new genus may belong to a separate, undescribed family.

Magniscapa alligans (Aristov et Rasnitsyn, 2009), comb.n.

MATERIAL. Holotype PIN 3353/447 \pm with 3D-preserved body, and probably also specimen PIN 3353/536 (listed among paratypes of Soyania logica Aristov et Rasnitsyn, 2009); Soyana R. (Iva-Gora, Sheimo-Gora), Arkhangelsk Region; Iva-Gora Beds, Lower Kazanian, Middle Permian.

DESCRIPTION (Figs 15-18). Small, body (with caudal appendages, without antennae) $5.6 \mathrm{~mm}$, forewing $5.3 \mathrm{~mm}$, hind wing $4.2 \mathrm{~mm}$ long (holotype). Wings homonomous, elongate (forewing ca. 3:1), widened towards midlength, acuminate at apex; hind wings shorter than forewings (apices of fore and hind wings about same level in repose); costal margin nearly straight before midlength; preradial space much narrowed distally; Sc nearly parallel to R-RA, entering RA which distally curved along wing margin and almost reaching wing apex; $\mathrm{RP}+\mathrm{MA}$ anastomosis absent; RP simple, joining RA apex. Forewing: Sc reaching beyond $2 / 3$ wing length; $R$ forked at $1 / 3$ wing length, $M$ forked just distal to it, MA simple, MP forked; CuA forked just beyond wing midlength; anal area narrow triangular, possibly with two anal veins; crossveins distinct, numerous, close-set. Hind wing: Sc reaching beyond wing midlength; $\mathrm{R}$ forked at 

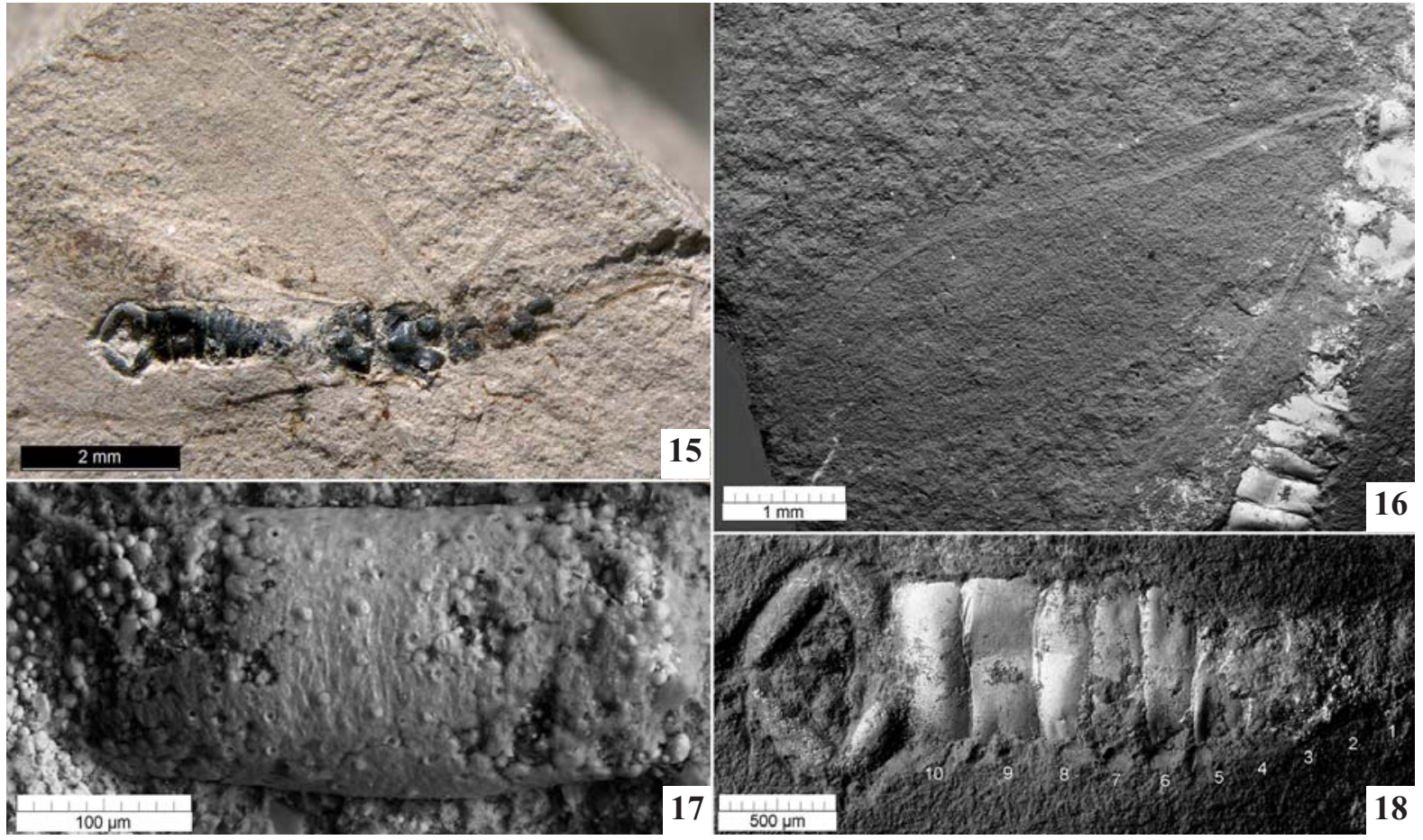

Figs 15-18. Magniscapa alligans (Aristov et Rasnitsyn, 2009), comb.n., Soyana, Middle Permian, holotype male? PIN 3353/447, positive impression: 15 - habitus; 16 - left wings; 17 - scape; 18 - abdomen (16-18 - SEM micrographs); abdominal segments numbered.

Рис. 15-18. Magniscapa alligans (Aristov et Rasnitsyn, 2009), comb.n., Сояна, средняя пермь, ?самец, голотип ПИН 3353/447, прямой отпечаток: 15 - облик; 16 - левые крылья; 17 - скапус; 18 - брюшко (16-18 - СЭМ микрофотографии); сегменты брюшка пронумерованы.

1/4 wing length. Head rounded; eyes rather large, rounded, slightly protruding; three widely separated ocelli in almost rectangular triangle; lateral ocelli at middle of eye margin. Antenna filiform, longer than thorax; scape very large and wide (longer than $1 / 2$ head, $1 / 5$ head width), ca. $2: 1$, with numerous campaniform sensillae (or just bases of strong setae) arranged in transverse series and minute tubercles in tangled transverse rows; pedicel shorter and narrower (see specimen $3353 / 536$ which is $12 \%$ smaller than holotype), flagellomeres (at least seven visible) even narrower and long, rodlike, up to 5:1. Pronotum subquadrate, shorter and narrower than head. Mesonotum as long as wide; mesoscutum rounded triangular with round, deeply convex lateral lobes and less convex posterior half raised in scutellar region; metanotum shorter, more transverse and triangular, with less convex lateral lobes and less developed posterior region; lateral lobes and posterior region of meso- and metascutum covered with imbricate microsculpture reinforced with minute tubercles, forming tangled concentric rows on lateral lobes; meso- and metapostnotum narrow. Legs poorly preserved, rather short; fore tibiae slender, longer than femora; mid and hind tibiae widened; tarsi short. Abdomen elongate (ca. 3.5:1), slightly widened towards apex, not reaching wing apices in repose; segments transverse (at least 1:2), proximal more so; $5-10$ th segments (occupying $2 / 3$ length of abdomen) fully 3D-preserved, 3 4th segments less finely so; tergites with imbricate microsculpture. 10th segment with low triangular posteromedian projection (better preserved in left half) between bases of widely separated, massive, two-segmented cerci; 2 nd cercomeres convergent, slightly tapered towards apex, longer and slenderer than divergent 1 st cercomeres.

\section{Family Soyaniidae Shcherbakov, fam.n.}

TYPE GENUS. Soyania Aristov et Rasnitsyn, 2009.

DIAGNOSIS. Distinct from Sheimiidae and Permembiidae in all main veins simple, wide, margined with membranous lines, the head wedge-shaped, and forelegs incrassate.

COMPOSITION. Type genus.

Soyania Aristov et Rasnitsyn, 2009

COMPOSITION. Type species.

\section{Soyania logica Aristov et Rasnitsyn, 2009}

MATERIAL. Holotype PIN 3353/350 \pm with 3D-preserved body, six paratypes (excluding PIN 3353/536 , see Remarks), and several other specimens; Soyana R. (Iva-Gora, Sheimo-Gora) and Letopala R., Arkhangelsk Region; Iva-Gora Beds, Lower Kazanian, Middle Permian.

DESCRIPTION (Figs 19-24). Body very long and slender, 5.6-6.4 mm long, with folded wings $6.4-7.4 \mathrm{~mm}$ long. Wings homonomous, narrow triangular, ca. 4:1, obliquely rounded at apex, forewings 5.3-5.8 mm long, hind wings shorter than forewings (apices of fore and hind wings about same level in repose); costal margin straight; preradial area narrow, even more so distally; Sc closely parallel to $\mathrm{C}$, reaching about $2 / 3$ forewing length; in forewing $\mathrm{R}$ forked at $1 / 3$ wing length, $M$ forked just distal to it, and moderately long RP+MA anastomosis ending about wing midlength; RA, RP, MA, MP, and CuA simple, in distal wing half unusually wide (especially RP and MA), flat, dark, each bordered from both sides (CuA only posteriorly) with wide, pale, probably hyaline stripes (especially wide posterior to apical RA, i.e. in pterostigmal area); wing membrane suffused, wrinkled; anal area greatly reduced. Head small, elon- 


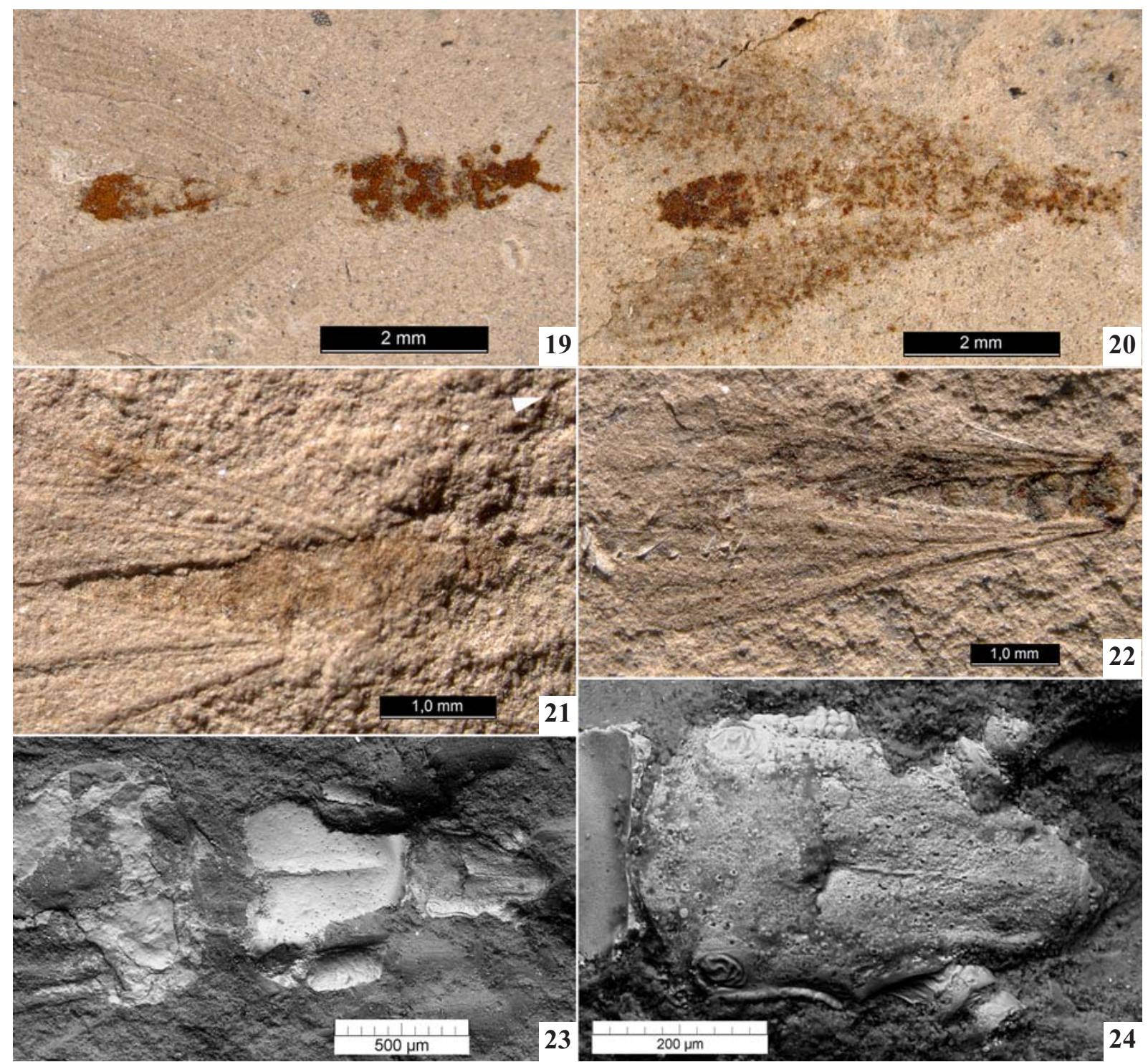

Figs 19-24. Soyania logica Aristov et Rasnitsyn, 2009, Soyana, Middle Permian: 19 - paratype PIN 3353/534, ?male; 20 - paratype PIN 3353/544, ?female; 21 - specimen PIN 117/1195, anterior part of body (arrow, apex of antenna); 22-24 — holotype PIN 3353/350: 22 - negative impression, wings; 23-24 - positive impression, SEM micrographs: 23 - anterior part of body; 24 - head.

Рис. 19-24. Soyania logica Aristov et Rasnitsyn, 2009, Сояна, средняя пермь: 19 — паратип ПИН 3353/534, ?самец; 20 - паратип ПИН 3353/544, ?самка; 21 - экз. ПИН 117/1195, передняя часть тела (стрелка, вершина усика); 22-24 — голотип ПИН 3353/350: 22 - обратный отпечаток, крылья; 23-24 - прямой отпечаток, СЭМ микрофотографии: 23 - передняя часть тела; 24 - голова.

gate triangular, wedge-shaped; three very large, widely separated ocelli in obtuse triangle; lateral ocelli at eye margin close to occiput; frontoclypeal area with median carina forked into two short subtransverse furrows just below median ocellus; antennae as long as two thoracic segments combined, of about 12 segments (specimen PIN 117/1195), proximally moniliform and of shorter and wider segments; scape short, not much wider than pedicel. Pronotum longer than wide, widest at $2 / 3$ length, much narrowed anteriorly, rounded posteriorly, with median furrow and concave lateral margins. Head and pronotum with bases of large setae. Meso- and metathorax wider than long; small subtriangular mesoscutellum delimited (paratype PIN 3353/175). Legs very short; forelegs modified, with incrassate femur and tibia, fore tibiae always preserved parallel to body axis. Abdomen widest in posterior third. Cerci very short, stump-like, about 2:1 (paratype PIN 3353/544).
REMARKS. The specimen PIN 3353/536 \pm listed among the paratypes does not belong to Soyania, differing from it and resembling Magniscapa alligans (Aristov et Rasnitsyn, 2009) in the hypertrophied scape and long antennomeres.

\section{Discussion}

On the names of the webspinner order. Names of taxa above superfamily rank are not regulated by the ICZN, so different names may be applied to the same higher taxon. Among several names in use for the webspinner order, the oldest one is Embiodea Kusnezov, 1903 published in August [Kusnezov, 1903], before Embiaria Handlirsch, 1903 (October) and Embioptera 
Shipley, 1904 [Engel, Grimaldi, 2006]. The name Embioptera, Latinization of the French vernacular "Embioptères" proposed by Lameere [1900], is often incorrectly dated from 1900 (by analogy with Article 11.7.2 of the Code) and considered the oldest one.

According to Kluge [2010], names of higher taxa are based either on their type genus or circumscription, and these two approaches are mutually exclusive. For those who believe that essential changes in the composition of a higher taxon require renaming it, a new name for Embiodea s.1. incl. Alexarasniidae is offered, Erectoptera nom. n., alluding to development of erectile blood sinuses in their wings. This word was first coined by A.P. Rasnitsyn as an informal name for the webspinner order.

On the age of the Babiy Kamen' insects. The Mal'tsevo (Maltseva) Formation is correlated to the Tutonchana and Dvurogii horizons, Tunguska Basin, all dated Lower Triassic in the regional stratigraphic scheme [Mogutcheva, Krugovykh, 2009], though some authors consider them terminal Permian [see: Shcherbakov, 2000; Bashkuev, 2013; Ponomarenko \& Volkov, 2013]. In the Babiy Kamen' section the tuffaceous argillites that yielded alexarasniids and most other insects are some $50 \mathrm{~m}$ below the basalts crowning the Mal'tsevo Formation. These basalts (Karakan sill) intruded at depths of several hundred meters, possibly into water-saturated rocks, $\sim 1$ Ma before the PermianTriassic boundary [Buslov et al., 2010]. Deposition of pyroclastic-rich rocks could be rapid, and if the above age is correct, the insect beds are probably less than 2 Ma older than the boundary, i.e. Changhsingian. Regardless of whether the insect beds of Babiy Kamen' are Triassic or Permian, they are close to the PermianTriassic boundary and contain one of the few diverse insect assemblages from this time interval [Shcherbakov et al., 2002; Shcherbakov 2008a, c].

Wings of Alexarasniidae and Euembiodea. Alexarasniidae were originally diagnosed from Embiodea by the distinctly more numerous longitudinal veins [Gorochov, 2011], but in fact it is not so: on $\mathrm{R}, \mathrm{M}$ and $\mathrm{CuA}$ combined there is $8-13$ branches in alexarasniids and up to 11-12 branches in webspinners. The vein named R4+5 in Embiodea after Comstock [1918] is in fact MA forming a long fusion (anastomosis) with RP (Comstock's R2+3), as shown by Martynov [1927] and Zeuner [1936] based on comparison with Protorthoptera, and by Ross [2000] based on wing tracheation. According to this vein nomenclature, in webspinners RA and RP are always simple, MA forked in more primitive taxa, MA1, MA2 and MP usually simple, and $\mathrm{CuA}$ with up to 5 (Clothodidae) or even 6 variably arranged branches (Embiidae: Berlandembia gromieri (Navás, 1934) [Davis, 1939c]. (In databases the species gromieri is listed under Embia, but it has been transferred to the genus Berlandiella Davis, 1939, later renamed as Berlandembia Davis, 1940, as very closely related to its type species, B. berlandi (Navás, 1922) [Davis, 1939c, 1940a].) Occasionally either MA1, or MA2, or MP, or two of these three veins bear a short fork [Davis, 1939a, fig. 3; 1939b, fig. 2; 1939c, fig. 7; 1940a, fig. 37; Ross, 1987: 13] or MA2 ends in 3 short branches (hind wing of Gibocercus sandrae Ross, 2001) [Ross, 2009, fig. 14]; in Biguembia multivenosa Ross, 2001 the MA1, MA2 and MP are all three forked [Ross, 2001]. The $\mathrm{CuA}$ branch arrangement may vary within a single species [see e.g. Davis, 1939c, figs 7, 10; Kluge, 2012 , fig. 8]. Likewise Alexarasniidae have the RA simple, RP, MA and MP simple or forked, and $\mathrm{CuA}$ with 4-8 variably arranged branches.

In the number of $\mathrm{CuA}$ branches Nestorembiinae are more similar to the modern-type webspinners than Alexarasniinae. In Nikolembia gen.n. and Nestorembiinae the $\mathrm{CuA} 1$ is branched and CuA2 simple, like in most webspinners retaining more than two branches on $\mathrm{CuA}$, but in alexarasniids all $\mathrm{CuA}$ branches are weak, in contrast to Euembioidea having the strong $\mathrm{CuA}-\mathrm{CuA} 2$ to support the wing blade when turgescent. The MP is deeply forked in Nestorembia gen.n. and modern Donaconethis Enderlein, 1909 [Enderlein, 1912, figs 8-9].

In contrast to alexarasniids, the anal area of webspinners is usually narrow, with only one simple anal vein, though in some species of Archembia it is relatively broad and in A. batesi (McLachlan, 1877) provided with a short second anal vein in the forewing [Davis, 1940b, fig. 9; Ross, 2000, figs 25B, 27].

In webspinner wings, intercalary veins transformed into the hyaline folds running along the midline of most spaces were termed Intervenallinien (intervenal lines), and the membranous, partly fleshy lines bordering RA were named Radiussamenlinien (Radiolimbolarien) by Enderlein [1909]; the latter term was translated as radial lines [Imms, 1913], radial border lines [Comstock, 1918], or radius margin lines [Ross, 2000]. Usually only intercalaries (intervenal lines) are looped in webspinners [see e.g. Ross, 2000, figs. 24, 25], but in Andesembiidae the $1 \mathrm{~A}, \mathrm{CuA} 2, \mathrm{CuA} 1$ and MP (represented by pigment bands) are looped along the wing margin to form an ambient vein reaching the wing apex [Ross, 2003, fig. 7] like in Nestorembiinae.

In Euembiodea, the hind wing is very similar to the forewing but generally shorter, relatively wider, rather oval than parallel-sided, narrower at base and towards apex, with longitudinal veins more divergent, RA more arched, anal area shorter, and preradial area often narrower. Similar differences are observed among several isolated wings of Alexarasniidae, indicating that both hind and forewings are represented in this material and that their homonomy is of the same kind as in modern webspinners.

The wings of Alexarasniidae are similar to those of Embiodea in many important respects: size, shape, texture, number and distribution of vein branches, basal position of both $\mathrm{R}$ and $\mathrm{M}$ bifurcations, presence of radial border lines indicating development of turgescent radial blood sinus, transformation of intercalaries into hyaline folds and their looping or deflection along posterior margin (along with main veins' looping which is rarely developed in webspinners). However, these 
similarities were not noticed before, because even the wings of the most primitive, relatively polyneurous webspinners look dissimilar to those of Alexarasniidae. The main reason is that the latter have not acquired yet the RP+MA fusion, so that RA, RP, MA and MP run closely parallel to each other from near the wing base, making the alexarasniid venation pattern so peculiar.

Despite these differences in the venation pattern and lack of knowledge on the body structure, there is little doubt that Alexarasniidae represent the group ancestral to the modern-type webspinners and may be included into the order Embiodea in a broader sense as a new suborder, Palembiodea subordo n. opposed to the suborder Euembiodea nom.n. (=Embioptera s.str.) comprising all extant families.

The hyaline intercalaries function as folds facilitating flexibility of webspinner wings. In Alexarasniinae the concave intercalary between two branches of apparent medial vein (interpreted here as MA and MP) is proximally deeper and running close to MP. Association with the medial fold indicates that this $\mathrm{M}$ branch belongs to MP, not to MA as suggested by Gorochov [2011]. This branch is interpreted here as representing the entire MP, and all the branches from the $\mathrm{CuA}$ stem as cubital; this vein homology is in accordance with that for Euembiodea (and that for Atactophlebiidae by Martynov [1930a], see below). Alternatively, the vein associated with the medial fold may be the anteriormost MP branch (MP1), other MP branches being captured by $\mathrm{CuA}$; however, this homology implies that the $\mathrm{CuA}$ includes MP branches in Euembiodea.

It is remarkable that the interradial fold (intervenal line between RA and RP) became gradually suppressed in Embiodea, being developed only distally in Alexarasniidae and at most slightly indicated in Euembiodea [Fig. 1; Ross, 2000, figs 24, 29, 30]. Instead the R-RA, the strongest and widest vein in webspinner wings containing the main blood sinus is bordered from both sides with pale stripes often containing brightly coloured, fleshy lines - radial border lines, developed along RA in Alexarasniidae and for most of wing length in Euembiodea. The replacement of the interradial fold with radial border folds in the evolution of Embiodea and the posterior deflection of the intermedial fold to border MP in Alexarasniinae show that the intercalary and border folds are elements of one flexion line system. Therefore facilitating inflation of the radial blood sinus is not the only and probably secondary function of the radial border stripes.

On Protorthoptera and related groups. Many orders and suborders were proposed for largely Paleozoic groups considered ancestral or related to the extant orders that are now classified in Polyneoptera: Protorthoptera, Protoblattoidea, Hadentomoidea, Hapalopteroidea and Cnemidolestoidea [Handlirsch, 1906-1908, 1937] (endings "-oidea" were later changed to "-odea"), Paraplecoptera [Martynov, 1925], Protoperlaria [Tillyard, 1926, 1928a], Miomoptera [Martynov, 1927], and Embiopsocida (proposed as suborder of Copeognatha having also some relationships with Embiodea) [Tillyard, 1928c].
It was shown that Miomoptera and Embiopsocida are based on the same family, Palaeomanteidae (=Delopteridae) [Martynov, 1930b]. Miomoptera was considered an artificial assemblage by Tillyard [1928b] and restricted to Palaeomanteidae by Martynov [1937]. Paraplecoptera united with Protoperlaria [Sharov, 1961] were merged with living Notoptera under the name Grylloblattida (typified names Eoblattida and Palaeomanteida were introduced also for Protoblattoidea and Miomoptera); the order Miomoptera was expanded to include some other families and reconsidered as the most basal group of Oligoneoptera [Rasnitsyn, 1980; Aristov \& Rasnitsyn, 2009; Rasnitsyn \& Aristov, 2013], but this interpretation is disputed [Shcherbakov, 1999; Nel et al., 2012]. Despite many efforts to systematize protorthopterans and related groups, the latest classifications look no more justified than the earlier ones, so Protorthoptera are referred to here in the broadest sense [Carpenter, 1992], i.e. including Protoblattodea, Cnemidolestodea, and Paraplecoptera.

Paleozoic fossils. Several Permian fossils were formerly assigned to Embiodea. The families Protembiidae, Tillyardembiidae, and Sheimiidae from the Lower and Middle Permian of Kansas and European Russia were described in the webspinner order as suborders Protembiaria, Epiembiodea and Sheimiodea, respectively [Tillyard, 1937b; Zalessky, 1937, 1938; Martynova, 1958]. All three families are based on the insects somewhat resembling webspinners in the overall body structure and wing shape, but with winged females retaining ovipositor, multisegmented cerci, and unmodified fore tarsi. Subsequently the former two families were transferred to Protorthoptera s.l. [Carpenter, 1950], then all the three were included in Grylloblattodea [Rasnitsyn, 1980; Storozhenko, 1997], and later moved to three different orders: Protoblattodea (Protembiidae, Tillyardembiidae) [Aristov \& Rasnitsyn, 2010, 2011a], Cnemidolestodea (Tillyardembiidae) [Aristov, 2014], and Miomoptera (Sheimiidae) [Aristov, Rasnitsyn, 2009].

The genus Permembia Tillyard, 1928 from the Lower Permian of Kansas was described in the family Delopteridae of the suborder Embiopsocida [Tillyard, 1928c], and later singled out into a separate family [Tillyard, 1937a]. The family Permembiidae was kept in Miomoptera [Kukalová, 1963; Riek, 1973], then transferred to the insects of uncertain ordinal position (probably orthopteroid) [Carpenter, 1976], Grylloblattodea [Storozhenko, 1997], and back to Miomoptera [Aristov, Rasnitsyn, 2009].

Some other, unnamed fossils from the Lower Permian of the Urals were mentioned as the oldest Embioptera [Kukalova-Peck, 1991], but this ordinal assignment was doubted [Engel, Grimaldi, 2006]. The genus Megagnatha Bolton, 1917 from the Late Carboniferous of Commentry described in Plecoptera was singled out into a separate family and transferred to Embioptera by Tillyard [1918], but now is assigned to Protorthoptera [M. Engel, pers. comm. in Miller, 2009]. 
Atactophlebiidae. One more Permian group never mentioned as similar to webspinners, but clearly related to Alexarasniidae, is the family Atactophlebiidae. It was described in the order Miomoptera [Martynov, 1930a] and later transferred to Protoperlaria [Martynov, 1937], Paraplecoptera (superfamily Liomopteridea) [Sharov, 1961], Grylloblattodea [Rasnitsyn, 1980], Gerarida [Storozhenko, 1990], and back to Grylloblattodea (suborder Lemmatophorina) [Storozhenko, 1997].

The family comprises 5 genera from the Lower and Middle Permian of European Russia [Storozhenko, 1998; Aristov, 2004; Aristov et al., 2006; Aristov, Rasnitsyn, 2015]. Atactophebiids had the elongate body, stout legs with 5-segmented tarsi and very short 2-4th tarsomeres, and long multisegmented cerci [Storozhenko, 1998]. Their highly variable wing size $(22-43 \mathrm{~mm}$ in Atactophlebia termitoides Martynov, 1928) was interpreted as the evidence of three winged instars - two subimagoes and imago [Sharov, 1957]. However, another explanation seems much more plausible, different levels of adult brachyptery [Béthoux et al., 2005], the phenomenon occurring in the related orders Plecoptera [Hynes, 1976] and Embiodea [Ross, 2000], so that in some stoneflies the wing length varies twofold within one population and one sex [Gray, 2009]. The nymphs are known for the Lower Permian Kirkorella G. Zalessky, 1939 [Storozhenko, 1998; Aristov et al., 2006].

Atactophlebiids differ from alexarasniids in the much larger size (wings up to $90 \mathrm{~mm}$ long), more vein branching, rudimentary intercalary veins, forewings with numerous well-developed crossveins, and hind wings with expanded anal area; no trace of blood sinuses is found. However, the genus Atactophlebia Martynov, 1928 (Fig. 25 ) is similar to Alexarasniidae in the forewing shape and venation pattern (proximal $\mathrm{R}$ and $\mathrm{M}$ forks, RP less branched than $\mathrm{CuA}$, anal area short, and even in the $\mathrm{CuA}$ branches and intercalaries forming loops along posterior margin in some forewings) [Martynov, 1930a, figs 23 ] enough to be considered presumed ancestor of the latter family.

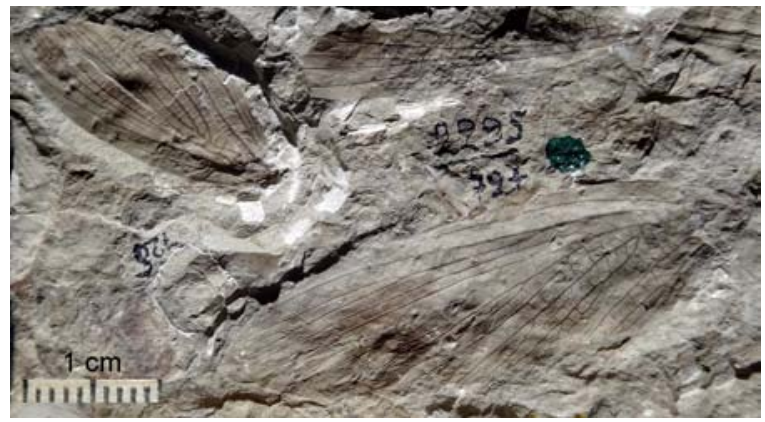

Fig. 25. Atactophlebia termitoides Martynov, 1928, Tikhie Gory, Middle Permian, mass burial, three paratype forewings, including one of the largest PIN 2295/72 and the smallest 2295/45, positive impressions.

Рис. 25. Atactophlebia termitoides Martynov, 1928, Тихие Горы, средняя пермь, массовое захоронение, три паратипа, передние крылья, включая одно из самых больших ПИН 2295/ 72 и самое маленькое 2295/45, прямые отпечатки.
Sheimiidae. This family, long known from a single specimen, was recently supplemented with several genera and species and (as well as Letopalopteridae) reduced to the subfamily in Permembiidae [Aristov, 2004; Aristov, Rasnitsyn, 2009]. Ross [2000] observed a slight indication of the radial border lines in the holotype of Sheimia sojanensis Martynova, 1958 and concluded that the family possibly belongs to the embiid stem group. I was unable to find the radial border lines in this specimen and other sheimiids from Soyana and Tshekarda, maybe because of their size smaller and preservation less fine than in alexarasniids from Isady and Babiy Kamen'.

The massive, two-segmented appendages at the abdominal apex of the insect described in Sheimiinae as Pseudosheimia alligans (known from the 3D-preserved holotype) were interpreted as forceps-like male gonopods consisting of gonocoxae and gonostyles and resembling those of some Oligoneoptera [Aristov, Rasnitsyn, 2009]. Two other species of Pseudosheimia, $P$. caudata Aristov, 2004 (type species) and P. caudissima Aristov et Rasnitsyn, 2009, are known from the holotypes with filiform multisegmented cerci, in the latter species longer than the abdomen. Such a difference in the structure of caudal appendages is difficult to explain with sexual dimorphism. If caudal appendages in the $P$. alligans holotype were male claspers, and the holotypes of two other species with filiform cerci were females, then such a case would be unique among Neoptera, finding parallels only in some Palaeoptera, namely in Palaeozoic Diaphanopterodea, whose males having claspers shed very long filiform cerci which persisted in females [Rasnitsyn, Novokshonov, 1997], or in Ephemeroptera whose males bear claspers in addition to filiform cerci. Six posterior abdominal segments of the $P$. alligans holotype are fully 3D-preserved, remaining segments less finely so, but it is easy to count 10 segments in total. Therefore the caudal appendages of this insect are two-segmented cerci arising from the 10th abdominal segment, and the abdomen widening to apex with cerci wide apart looks earwig-like (Figs 15, 18). Clasping male cerci are known in Orthoptera, Dermaptera and some protorthopteran families, such as Chelopteridae and Sylvaphlebiidae [Carpenter, 1950; Storozhenko, 1998]. Several differences of $P$. alligans from the other species of Pseudosheimia allow separating it into the genus Magniscapa gen.n. (see Taxonomy), and it needs to be proved that it is closely related to Sheimia and allies, because the wing venation of these minute insects has not yet been deciphered with confidence.

Reinterpretation of the two-segmented caudal appendages in Magniscapa alligans as cerci instead of male claspers eliminates the only argument in favor of assigning Sheimiidae and all Permembiidae sensu Aristov et Rasnitsyn, 2009 to the Miomoptera, the alleged order of Oligoneoptera. The differences between the type genera of Permembiidae, Sheimiidae and Letopalopteridae are more important than their superficial similarity due to more or less impoverished venation. Therefore these three are transferred in full family rank back 
to Protorthoptera s.1. The enlarged antennal scapes of Magniscapa gen.n. point out to its affinities with Notoptera and Embiodea [Crampton, 1917], and the twosegmented cerci and RP joining RA strengthen the latter relationship.

Soyanopteridae. None of the Paleozoic fossils discussed above is known definitely to possess the radial blood sinus with radial border lines, so clearly visible in the finely preserved wings of Alexarasnia and Nikolembia.

Nevertheless, a blood sinus in the radial system seems to be developed in yet another protorthopteran family. In the forewings of Upper Permian Poldarsia Aristov et Rasnitsyn, 2011 from Isady, described in the family Soyanopteridae (Lower-Upper Permian, Protoblattodea) [Aristov, Rasnitsyn, 2011b], a pale, smooth stripe is visible posterior to R-RP, contrasted with the suffused wing membrane densely covered with dark granular microtrichia; two isolated forewings are known, both preserved with the distal part folded over, demonstrating their great flexibility when the radial sinus was not inflated (Figs 26-28). For two other genera of this family known from the body fossils with wings less finely preserved, presence of such blood sinus is uncertain. A peculiar venation pattern (RP running closely parallel to RA, cubital and anal veins shortened, anal area very narrow) and some body characters, especially very large pronotal paranota, make soyanopterids dissimilar to Embiodea and their close relationship unlikely. The inflatable sinus along R-RP appeared in Soyanopteridae independently of Embiodea.

Soyaniidae. One more genus from the classic Middle Permian fossil site Soyana, Soyania Aristov et Rasnitsyn, 2009 described in Sheimiinae and separated into the family of its own herein, shows several embiid or near-embiid characters, including the presumed sinus veins. Very narrow, homonomous wings of Soyania are peculiar in the five main veins (from RA to $\mathrm{CuA}$ ) in distal wing half being simple, unusually wide, flat, dark, bordered from both sides ( $\mathrm{CuA}$ only posteriorly) with wide, pale, probably hyaline stripes contrasting against the suffused wing membrane. These pale stripes presumably functioned as the vein border lines allowing the blood sinus veins to inflate greatly, and as folds allowing the distal wing half to flex freely when not turgescent. In contrast to Embiodea s.l. having only one fold along the midline of each space, soyaniids have two folds bordering each space from both sides. Such a fold system apparently evolved after full suppression of intercalary veins, which were retained in alexarasniid ancestors. Soyaniid wings with five sinus veins arranged fan-like were heavier and less effective than the webspinner wings with the blade supported by the radial and cubital spar. Blood sinuses along veins developed in Soyanopteridae and Soyaniidae should be looked for in other protorthopterans as well.

Soyaniids were slender insects with very slim, flexile body, very short legs, apparently digging forelegs,

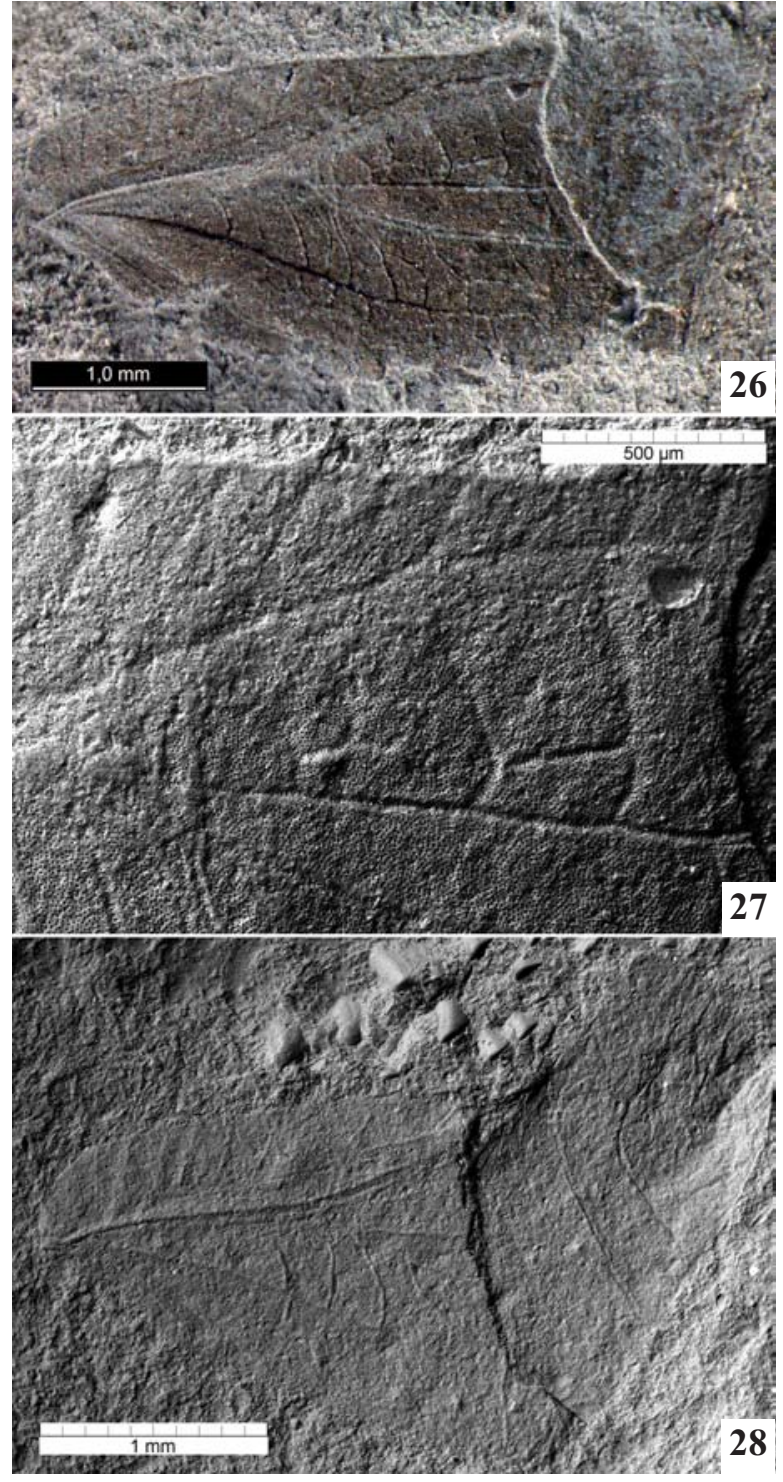

Figs 26-28. Poldarsia relictaria Aristov et Rasnitsyn, 2011, Isady, Upper Permian: 26-27 — holotype forewing, negative impression; 28 - paratype forewing PIN 3840/2040, negative impression (27-28 - SEM micrographs).

Pис. 26-28. Poldarsia relictaria Aristov et Rasnitsyn, 2011, Исады, верхняя пермь: 26-27 - голотип, переднее крыло, обратный отпечаток; 28 - паратип ПИН 3840/2040, переднее крыло, обратный отпечаток (27-28 - СЭМ микрофотографии).

narrow flexible wings with the long RP+MA anastomosis and erectile veins allowing backward movement in confined spaces, possibly subterranean lifestyle, and judging from their very large ocelli, nocturnal flight activity. So far as the hypothesized sinus vein system of soyaniids is only in part homologous to that of webspinners, they may be referred to only as "quasi-embiids."

Jurassic fossils. The family Sinembiidae from the Jurassic of Daohugou was described as the oldest Embiodea possessing the long RP+MA fusion, subcostal and cubital blood sinuses, enlarged hind femora, three-segmented tarsi, slightly enlarged probasitarsus, three-seg- 
mented cerci, and overall similarity to modern webspinners [Huang, Nel, 2009]. E.S. Ross [pers. comm. in Engel et al., 2011] excluded them from this order based on the well-developed ovipositor, winged females, absence of radial blood sinus, cerci of more than two segments, and probasitarsus not swollen. Nevertheless, Sinembiidae showing many webspinner characters bridge the gap between Palembiodea and Euembiodea, and may be included in the latter suborder in a broader sense on account of the RP+MA fusion, enlarged hind femora, three-segmented tarsi, and cerci of few segments.

The family Brachyphyllophagidae Rasnitsyn, 2000 from the Jurassic of Karatau was treated as a satellite taxon of Embiodea, mainly on account of supposedly similar head structure (development of postoccipital bridge) [Rasnitsyn, Krassilov, 2000], but the broad anal fan in hind wings contradicts this assumption.

On the origin of webspinners. The order Embiodea is one of relicts of the large and diverse, largely Paleozoic group, Protorthoptera s.l. [Tillyard, 1923]. Many authors traced the webspinner lineage into the Paleozoic, considering some Carboniferous or Permian families to be related, ancestral, or even belonging to webspinners: Hadentomidae [Handlirsch, 1906-1908], Megagnathidae [Tillyard, 1918], Probnisidae and Palaeomanteidae [Martynov, 1927], Lemmatophoridae [Zeuner, 1936], Permembiidae, Protembiidae, Tillyardembiidae, or Sheimiidae (see above). All these families are currently assigned to Protorthoptera s.l. or Miomoptera.

Now a new, better candidate for the webspinner ancestor is revealed, the Permian-Triassic Alexarasniidae sharing several important characters with Embiodea in their wing structure. Of these characters, two are considered unique of this order, the radial blood sinus and hyaline intercalaries [Ross, 2000]. This is conclusive evidence that alexarasniids are directly ancestral to webspinners and can be included in the same order, despite that their body structure remains unknown.

In turn, Alexarasniidae are clearly derivable from Protorthoptera s.1., namely, from Atactophlebiidae or some related family. In most protorthopterans the wings are heteronomous in that the anal area is expanded in the hind wings. The wings of webspinners became secondarily homonomous [Storozhenko, 1997], contrary to Kluge [2012] who considered that Embiodea retained the primary wing homonomy.

One of the main characters distinguishing webspinner wings from the forewings of most Protorthoptera is that the RP+MA fusion is long, beginning close to the wing base [Zeuner, 1936] (rather short in forewings of the exceptional Biguembia multivenosa [Ross, 2001]). The MA is fused to RP in many families and genera of Protorthoptera, but in their forewings the fusion is short (except e.g. Dalduba Storozhenko, 1996; Lisca Sellards, 1909), more distal, and less common than in the hind wings where it may be long and proximal. Sometimes the fusion is present only in some individuals of the same species or only in one of two forewings of the same individual (e.g. in Lecorium Sellards, 1909) [Car- penter, 1935]. In Atactophlebiidae, the RP+MA fusion is rather long and proximal in the hind wings (Atactophlebia, Olgaephilus Storozhenko, 1990) and occasionally developed also in the forewings (some specimens of A. termitoides and Kirkorella mira G. Zalessky, 1939) [Storozhenko, 1998]. A long RP+MA fusion is present also in forewings of some Sheimiidae (Sheimia Martynova, 1958) and, according to the vein homology proposed by Martynov [1930b], in the wings of Palaeomanteidae, the central family of Miomoptera.

Alexarasniidae and webspinners are much smaller than Atactophlebiidae, and the noticeable size decrease in this lineage may be related to its evolutionary success. Miniaturization can be an important source of morphological novelty, in some cases resulting in the origin of higher taxa. It was hypothesized that Raphidioptera and Hymenoptera at their origins have passed through a "miniaturization bottleneck" [Shcherbakov, 2013]. Miniaturization likely has played a significant role in the origin of Embiodea.

Tatarinov [1972] described the origin of mammals as "mammalization" of theriodonts - gradual accumulation of the mammal characters in several parallel lineages, only one of them eventually acquiring all these characters. Such evolutionary pattern appears to be of general significance, and various "-zations" were mentioned since then. It seems quite probable that webspinners originated in a similar way. In several protorthopteran groups, some embiid features appeared by one, two or three, e.g. the sinus veins in Soyanopteridae and Soyaniidae, cerci of few (4 or 2) segments in Permembiidae s.str. and Magniscapa gen.n. (?Sheimiidae), the long RP+MA fusion in forewings of Soyaniidae, some Lemmatophoridae and Sheimiidae, slender embiid-like body in Permembiidae, Sheimiidae, Soyaniidae and some other families. However, the entire character set constituting the "embiid syndrome" evolved in the only lineage, Alexarasniidae + Euembiodea.

It is believed that the ability to produce silk galleries by action of modified forelegs was the key innovation in Embiodea, their slender body, short legs, enlarged hind femora, cerci of few segments, and flexible wings with sinus veins were adaptations to the life in galleries, and the blood sinus adaptation appeared rather late in the order's evolution [Ross, 1970, 2000]. However the fossil record shows quite the opposite: several latter characters including the sinus veins are found scattered over Permian protorthopterans and alexarasniids, much earlier than the first, Jurassic indication of the fore tarsi slightly modified for silk production in sinembiids. Thickened hind femora with tibial depressor hypertrophied for backward movement are present also in Zoraptera, Notoptera, Dermaptera and other insects adapted to crawling in narrow spaces [Kluge, 2012]. Apparently the flexible wings in Alexarasniidae, Soyaniidae and Soyanopteridae, as well as some other embiid characters in protorthopteran precursors, evolved for life in confined spaces, but not yet in silk galleries, and predate the foreleg modification and webspinning habit. 
ACKNOWLEDGEMENTS. I am deeply indebted to Alexei Bashkuev for preparing the fossils from Babiy Kamen' and bringing them to my attention, and to Roman Rakitov (both Borissiak Paleontological Institute RAS, Moscow) for taking scanning electron micrographs. The research was partly supported by the Russian Foundation for Basic Research, project no. 13-04-01839.

\section{References}

Aristov D.S. 2004. The fauna of grylloblattid insects (Grylloblattida) of the Lower Permian locality of Tshekarda // Paleontological Journal. Vol.38. Suppl.2. P.S80-S145.

Aristov D.S. 2014. Classification of the order Cnemidolestida (Insecta: Perlidea) with descriptions of new taxa // Far Eastern Entomologist. No.277. P.1-46.

Aristov D.S., Rasnitsyn A.P. 2009. Position and taxonomy of the Permian fossil insect family Permembiidae (Insecta: Palaeomanteida $=$ Miomoptera) $/ /$ Russian Entomological Journal Vol.17. P.327-334.

Aristov D.S., Rasnitsyn A.P. 2010. The family Tillyardembiidae Zalessky, 1938 and the system of the plecopteroid insects / Russian Entomological Journal. Vol.18. P. 257-264.

Aristov D.S., Rasnitsyn A.P. 2011a. A review of the family Protembiidae (Insecta: Eoblattida) // Russian Entomological Journal. Vol.20. P.119-127.

Aristov D.S., Rasnitsyn A.P. 2011b. A new eoblattids (Insecta: Eoblattida) from the Permian of Russia // Far Eastern Entomologist. No.230. P.1-12.

Aristov D.S., Rasnitsyn A.P. 2015. New insects from the Kungurian of Tshekarda fossil site in Permian Territory of Russia // Russian Entomological Journal. Vol.24. P.17-35

Aristov D.S., Novokshonov V.G. \& Pan'kov N.N. 2006. Taxonomy of the fossil grylloblattid nymphs (Insecta: Grylloblattida) // Paleontological Journal. Vol.40. P.79-89.

Aristov D.S., Grauvogel-Stamm L., Marchal-Papier F. 2011. New grylloblattid insects (Insecta: Grylloblattida) from the Grès à Voltzia of the Vosges (Middle Triassic of France) // Paleontological Journal. Vol.45. P.159-166.

Bashkuev A.S. 2013. New Mecoptera from the end-Permian intertrappean deposits of the Tunguska Basin // Russian Entomological Journal. Vol.22. P.1-4.

Béthoux O., Nel A., Lapeyrie J., Gand G. 2005. New data on Paleozoic grylloblattid insects (Neoptera) // Journal of Paleontology. Vol.79. P.125-138.

Buslov M.M., Safonova I.Yu., Fedoseev G.S., Reichow M., Davies K., Babin G.A. 2010. Permo-Triassic plume magmatism of the Kuznetsk Basin, Central Asia: geology, geochronology, geochemistry, and geodynamic consequences // Russian Geology and Geophysics. Vol.51. P.1021-1036.

Carpenter F.M. 1935. The Lower Permian insects of Kansas. Part 7 The order Protoperlaria // Proceedings of the American Academy of Arts and Sciences. Vol.70. P.103-146.

Carpenter F.M. 1950. The Lower Permian insects of Kansas. Part 10. The order Protorthoptera: The family Liomopteridae and its relatives // Proceedings of the American Academy of Arts and Sciences. Vol.78. P.185-219.

Carpenter F.M. 1976. The Lower Permian insects of Kansas. Part 12 Protorthoptera (continued), Neuroptera, additional Palaeodictyoptera, and families of uncertain position // Psyche. Vol.83 P.336-378.

Carpenter F.M. 1992. Superclass Hexapoda // Treatise on Invertebrate Paleontology. Part R, Arthropoda 4. Vols 3-4. P.1-655.

Cockerell T.D.A. 1919. Two interesting insects in Burmese amber // The Entomologist. Vol.52: P.193-195.

Comstock J.H. 1918. The Wings of Insects. Ithaca: Comstock Publishing Co. $430 \mathrm{p}$

Crampton G.C. 1917. A comparison of the antennae of the Grylloblattidae and Embiidae to demonstrate the relationship of these two groups of insects // The Canadian Entomologist. Vol.49. P. 213-217.
Davis C. 1939a. Taxonomic notes on the order Embioptera. IV. The genus Clothoda Enderlein // Proceedings of the Linnean Society of New South Wales. Vol.64. P.373-380.

Davis C. 1939b. Taxonomic notes on the order Embioptera. V. The genus Donaconethis Enderlein // Proceedings of the Linnean Society of New South Wales. Vol.64. P.381-384.

Davis C. 1939c. Taxonomic notes on the order Embioptera. Part XIII: A new West African genus // Proceedings of the Linnean Society of New South Wales. Vol.64. P.567-572.

Davis C. 1940a. Taxonomic notes on the order Embioptera. XV. The genus Rhagadochir Enderlein, and genera convergent to it // Proceedings of the Linnean Society of New South Wales. Vol.65. P.171-191

Davis C. 1940b. Taxonomic notes on the order Embioptera. XVII. A new neotropical genus previously confused with Embia Latreille // Proceedings of the Linnean Society of New South Wales. Vol.65. P.344-352.

Enderlein G. 1909. Die Klassifikation der Embiidinen, nebst morphologischen und physiologischen Bemerkungen, besonders über das Spinnen derselben // Zoologischer Anzeiger. Vol.35. P.166-191.

Enderlein G. 1912. Embiidinen Monographische Bearbeitet // Collections Zoologiques du Baron Edm. de Selys Longchamps. Vol.3. P.1-121

Engel M.S., Grimaldi D.A. 2006. The earliest webspinners (Insecta: Embiodea) // American Museum Novitates. No.3514. P.1-15.

Engel M.S., Grimaldi D.A., Singh H., Nascimbene P.C. 2011. Webspinners in Early Eocene amber from western India (Insecta, Embiodea) // ZooKeys. No.148. P.197-208.

Golubev V.K. 2013. Historical geology // Aristov D.S. et al. Fossil insects of the Middle and Upper Permian of European Russia. Paleontological Journal. Vol.47. P.651-658.

Gorochov A.V. 2011. A new, enigmatic family for new genus and species of Polyneoptera from the Upper Permian of Russia // ZooKeys. No.130. P.131-136.

Gray D.P. 2009. A new species of Zelandobius (Plecoptera: Gripopterygidae: Antarctoperlinae) from the upper Rangitata River, Canterbury, New Zealand // New Zealand Journal of Marine and Freshwater Research. Vol.43. P.605-611.

Handlirsch A. 1906-1908. Die fossilen Insekten und die Phylogenie der rezenten Formen. Leipzig: W. Engelmann. 1430 p.

Handlirsch A. 1937. Neue Untersuchungen über die fossilen Insekten mit Ergänzungen und Nachträgen sowie Ausblicken auf phylogenetische, palaeogeographische und allgemein biologische Probleme. I. Teil // Annalen des Naturhistorischen Museums in Wien. Vol.48. P.1-140.

Huang D.-Y., Nel A. 2009. Oldest webspinners from the Middle Jurassic of Inner Mongolia, China (Insecta: Embiodea) // Zoological Journal of the Linnean Society. Vol.156. P.889-895.

Hynes H.B.N. 1976. Biology of Plecoptera // Annual Review of Entomology. Vol.21. P.135-153.

Imms A.D. 1913. Contributions to a knowledge of the structure and biology of some Indian insects. - II. On Embia major, sp. nov., from the Himalayas // Transactions of the Linnean Society, London. V.11. P.167-195.

Kluge N.J. 2010. Circumscriptional names of higher taxa in Hexapoda // Bionomina. No.1. P.15-55.

Kluge N.J. 2012. General system of Neoptera with description of a new species of Embioptera // Russian Entomological Journal. Vol.21. P.371-384.

Kukalová J. 1963. Permian insects of Moravia. Part I - Miomoptera // Sborník Geologickıch Ved, Paleontologie. Vol.1. P.7-52.

Kukalová-Peck J. 1991. Fossil history and the evolution of hexapod structures // Naumann I.D. (ed.). The Insects of Australia. Vol.1 (2nd edn.). Carlton: Melbourne University Press. P.141-179.

Kusnezov N.J. 1903. A new species of Embia Latr. from the Crimea (Neuroptera, Embiodea) (preliminary description)//Revue Russe d'Entomologie. Vol.3. P.208-210.

Lameere A. 1900. Manuel de la faune de Belgique: Tome II, Insectes inférieurs. Bruxelles: H. Lamertin. 858 p.

Martynov A.V. 1925. [On a new form of Orthopteroidea from Permian deposits of South Ussuri Region] // Comptes rendus de l'Académie des Sciences de Russie. 1925. P.41-44 [in Russian]. 
Martynov A.V. 1927. Über eine neue Ordnung der fossilen Insekten, Miomoptera nov. // Zoologischer Anzeiger. Vol.72. P.99-109.

Martynov A. 1930a. Permian fossil insects from Tikhije Gory. Order Miomoptera. First part. The new fam. Atactophlebiidae and its relations // Bulletin de l'Académie des Sciences de l'URSS. Ser.7. No.9. P.951-975.

Martynov A. 1930b. Permian fossil insects from Tikhije Gory. Order Miomoptera. Second part. The fam. Lemmatophoridae and Palaeomantidae // Bulletin de l'Académie des Sciences de l'URSS. Ser.7. No.10. P.1115-1134.

Martynov A.V. 1937. Liassic insects of Shurab and Kizil-Kiya // Transactions of the Paleontological Institute of the USSR Academy of Sciences. Vol.7. Pt.1. P.1-232.

Martynova O.M. 1958. [New insects from the Permian and Mesozoic deposits of the USSR] // Materialy po Osnovam paleontologii. Vol.2. P.69-94 [in Russian].

Miller K.B. 2009. Genus- and family-group names in the order Embioptera (Insecta) // Zootaxa. No.2055. P.1-34.

Mogutcheva N.K., Krugovykh V.V. 2009. New data on the stratigraphic chart for Triassic deposits in the Tunguska syneclise and Kuznetsk basin // Stratigraphy and Geological Correlation. Vol.17. No.5. P.510-518.

Nel A., Prokop J., Nel P., Grandcolas P., Huang D.-Y., Roques P., Guilbert E., Dostál O., Szwedo J. 2012. Traits and evolution of wing venation pattern in paraneopteran insects // Journal of Morphology. Vol.273. P.480-506.

Ponomarenko A.G., Volkov A.N. 2013. Ademosynoides asiaticus Martynov, 1936, the earliest known member of an extant beetle family (Insecta, Coleoptera, Trachypachidae) // Paleontological Journal. Vol.47. P.601-606.

Rasnitsyn A.P. 1980. [Order Palaeomanteida. Order Eoblattida. Superorder Perlidea. Order Grylloblattida] // [Historical Development of the Class Insecta.] Transactions of the Paleontological Institute of the USSR Academy of Sciences. Vol.178. P.74, 138, 148-154 [in Russian].

Rasnitsyn A.P., Aristov D.S. 2013. New fossil insects (Insecta: Caloneurida, Hypoperlida, Palaeomanteida, Jurinida) from the Middle and Upper Permian of European Russia // Paleontological Journal. Vol.47. P.678-704.

Rasnitsyn A.P., Krassilov V.A. 2000. The first documented occurrence of phyllophagy in pre-Cretaceous insects: leaf tissues in the gut of Upper Jurassic insects from Southern Kazakhstan // Paleontological Journal. Vol.34. P.301-309.

Rasnitsyn A.P., Novokshonov V.G. 1997. On the morphology of Uralia maculata (Insecta: Diaphanopterida) from the Early Permian (Kungurian) of Ural (Russia) // Entomologica Scandinavica. Vol.28. P.27-38

Riek E.F. 1973. Fossil insects from the Upper Permian of Natal, South Africa // Annals of the Natal Museum. Vol.21. P.513-532.

Ross E.S. 1940. A revision of the Embioptera of North America// Annals of the Entomological Society of America. Vol.33. P.629-676

Ross E.S. 1944. A revision of the Embioptera, or webspinners, of the New World // Proceedings of the United States National Museum. Vol.94. P.401-504.

Ross E.S. 1970. Biosystematics of the Embioptera // Annual Review of Entomology. Vol.15. P.157-172.

Ross E.S. 1987. Studies in the insect order Embiidina: A revision of the family Clothodidae // Proceedings of the California Academy of Sciences. Vol.45. P.9-34.

Ross E.S. 2000. EMBIA: Contributions to the biosystematics of the insect order Embiidina. Parts 1-2 // Occasional Papers of the California Academy of Sciences. No.149. P.1-53+1-36.

Ross E.S. 2001. EMBIA: Contributions to the biosystematics of the insect order Embiidina. Part 3. The Embiidae of the Americas (order Embidiina) // Occasional Papers of the California Academy of Sciences. No.150. P.1-86.

Ross E.S. 2003. EMBIA: Contributions to the biosystematics of the insect order Embiidina. Part 4. Andesembiidae, a new Andean family of Embiidina // Occasional Papers of the California Academy of Sciences. No.153. P.1-13.

Ross E.S. 2009. Lifelong safari: the story of a 93-year-old peripatetic insect hunter // Annual Review of Entomology. Vol.54. P.1-16.

Sharov A.G. 1957. [Types of insect metamorphosis and their rela- tionships (according to comparative ontogeny and paleontology)] // Entomologicheskoe obozrenie. Vol.36. P.569-576 [in Russian, with English summary].

Sharov A.G. 1961. [Order Protoblattodea. Order Paraplecoptera] // [Paleozoic Insects of the Kuznetsk Basin.] Transactions of the Paleontological Institute of the USSR Academy of Sciences. Vol.85. P.157-224 [in Russian].

Shcherbakov D.E. 1999. Controversies over the insect origin revisited // Proceedings of the First International Palaeoentomological Conference, Moscow 1998. Bratislava: AMBA projects. P.141-148.

Shcherbakov D.E. 2000. Permian faunas of Homoptera (Hemiptera) in relation to phytogeography and the Permo-Triassic crisis // Paleontological Journal. Vol.34. Suppl.3: P.S251-S267.

Shcherbakov D.E. 2008a. On Permian and Triassic insect faunas in relation to biogeography and the Permian-Triassic crisis // Paleontological Journal. Vol.42. P.15-31.

Shcherbakov D.E. 2008b. Madygen, Triassic Lagerstätte number one, before and after Sharov // Alavesia. No.2. P.113-124.

Shcherbakov D.E. 2008c. Insect recovery after the Permian/Triassic crisis // Alavesia. No.2. P.125-131.

Shcherbakov D.E. 2013. Permian ancestors of Hymenoptera and Raphidioptera // ZooKeys. No.358. P.45-67.

Shcherbakov D.E., Kabanov P.B., Ponomarenko A.G., Esin D.N 2002. [News on the fauna and lithology of the Mal'tsevo Group, Kuznetsk Basin] // 4th All-Russian Conference "Permian and Triassic paleontology and stratigraphy of North Eurasia", Moscow: Paleontological Institute RAS. P.100-101 [in Russian].

Storozhenko S.Yu. 1990. Permian fossil insects of North-East Europa: revision of the family Atactophlebiidae (Ins. Gerarida, Atactophlebiidae) // Deutsche Entomologische Zeitschrift. Vol.37. P.407-412.

Storozhenko S.Yu. 1997. Fossil history and phylogeny of orthopteroid insects // Ganwere S.K. et al. (eds). The Bionomics of Grasshoppers, Katydids and Their Kin. Wallingford, UK: CAB International. P.59-82.

Storozhenko S.Yu. 1998. [Systematics, phylogeny and evolution of the grylloblattids (Insecta: Grylloblattida).] Vladivostok: Dal'nauka. 207 p. [in Russian].

Tatarinov L.P. 1972. Paleontology and the phylogenetic laws of lower terrestrial vertebrates // Paleontological Journal. Vol.6. P.389-398.

Tillyard R.J. 1918. On the affinities of two interesting fossil insects from the Upper Carboniferous of Commentry, France // Proceedings of the Linnean Society of New South Wales. Vol.43. P.123-134

Tillyard R.J. 1923. The Embioptera or web-spinners of Western Australia // Journal and Proceedings of the Royal Society of Western Australia. Vol.9. P.61-68.

Tillyard R.J. 1926. Fossil insects in relation to living forms // Nature. Vol.2954. P.828-830.

Tillyard R.J. 1928a. Kansas Permian insects. Part 10. The new order Protoperlaria: a study of the typical genus Lemmatophora Sellards // American Journal of Science. Ser.5. Vol.16. P.185-220.

Tillyard R.J. 1928b. Kansas Permian insects. Part 11. Order Protoperlaria: family Lemmatophoridae (continued) // American Journal of Science. Ser.5. Vol.16. P.314-348.

Tillyard R.J. 1928c. Kansas Permian insects. Part 12. The family Delopteridae, with a discussion of its ordinal position // American Journal of Science. Ser.5. Vol.16. P.469-484.

Tillyard R.J. 1937a. Kansas Permian insects. Part 17. The order Megasecoptera and additions to the Palaeodictyoptera, Odonata, Protoperlaria, Copeognatha, and Neuroptera // American Journal of Science. Ser.5. Vol.33. P.81-110.

Tillyard R.J. 1937b. Kansas Permian insects. Part 18. The order Embiaria // American Journal of Science. Ser.5. Vol.33. P.241-251.

Zalessky G. 1937. Ancestors of some groups of the present-day insects // Nature. Vol.140. P.847-848.

Zalessky G. 1938. Nouveaux Insectes permiens de 1'ordre des Embiodea // Annales de la Société Géologique du Nord. Vol.63. P.62-81.

Zeuner F. 1936. Das erste Protoperlar aus europäischem Perm und die Abstammung der Embien // Jahrbuch der Preussischen Geologischen Landesanstalt. Vol.56. P.266-273. 